\title{
Lactose intolerance, detected by the hydrogen breath test, in infants and children with chronic diarrhoea
}

\author{
H. V. L. MAFFEI, G. METZ, V. BAMPOE, M. SHINER, S. HERMAN, AND \\ C. G. D. BROOK
}

From the MRC Gastroenterology Unit and Paediatric Department, Central Middlesex Hospital, London

SUMMARY Twenty-three infants and children aged $2 \frac{1}{2}$ months to 13 years with chronic diarrhoea and 6 patients without diarrhoea were investigated for lactose malabsorption with the hydrogen breath test (HBT) adapted for use in young infants and children. A further 8 children with proven or suspected coeliac disease were also investigated. The HBT was compared with the histology of the jejunal mucosa, mucosal lactase estimations, a lactose tolerance test, symptoms during the test, and follow-up after starting a lactose free diet.

The 6 patients without diarrhoea showed no evidence of hypolactasia and the hydrogen $\left(\mathrm{H}_{2}\right)^{*}$ concentration on the HBT was below 7 parts per million (ppm), a level considered to be clinically nonsignificant. 12 of the 23 patients with diarrhoea had a breath $\mathrm{H}_{2}$ concentration greater than $24 \mathrm{ppm}$ and this correlated well with their clinical symptoms during or after the test and with the remission of the diarrhoea after lactose withdrawal. Of the remaining 11 patients with diarrhoea whose breath $\mathrm{H}_{2}$ concentration was lower than $25 \mathrm{ppm}$, symptoms did not improve when a lactosefree diet was started in 3 , while a further 4 improved on a full diet.

There was poor correlation between the HBT and the findings on the jejunal mucosal specimens. All but one of the coeliac patients had an HBT less than $20 \mathrm{ppm}$ and none of these required lactose withdrawal for remission of symptoms. The HBT is a noninvasive test particularly suitable for outpatients and it gives a useful prognostic guide to the efficacy of lactose-free diet in the treatment of chronic diarrhoea in children.

Chronic diarrhoea is a major cause of morbidity in infants and children, secondary sugar malabsorption being a frequent perpetuating factor (Sunshine and Kretchmer, 1964; Levin et al., 1970). Most tests for diagnosing sugar malabsorption are not satisfactory for general use in children. Jejunal biopsy, with subsequent determination of disaccharidase activity in the mucosal specimen, is an invasive technique which is often poorly tolerated, and the enzyme estimation requires considerable laboratory expertise. Indirect methods like the oral sugar tolerance tests require multiple venepunctures and the results are frequently unreliable (Newcomer and McGill, 1966; Krasilnikoff et al., 1975). Detection of reducing substances in stools (Kerry and Anderson, 1964), though a simple and cheap bedside technique, may fail to establish the diagnosis in infants and children treated as outpatients; often they do not have

Received 24 February 1977

${ }^{*} 1 \mu \mathrm{mol} / 1 \mathrm{H}_{2}=22 \mathrm{ppm}$. diarrhoea until several hours after the tolerance test thus making the detection of the malabsorbed sugar in the stools more difficult.

Hydrogen is evolved when carbohydrate is fermented by bacteria (Calloway et al., 1966). Thus when malabsorbed lactose reaches the caecum it is fermented with production of $\mathrm{H}_{2}$ (Levitt, 1969). A proportion of the gas diffuses into the circulation, is transported to the lungs and exhaled (Levitt and Ingelfinger, 1968), and the expired $\mathrm{H}_{2}$ can be measured by gas chromatography (Bond and Levitt, 1972). Normal adults exhale little or no $\mathrm{H}_{2}$ after an overnight fast (Metz et al., 1976a). After a standard oral lactose load, adults with hypolactasia start to produce $\mathrm{H}_{2}$ at $60-90$ minutes and attain the peak concentration at about 120 minutes. The breath $\mathrm{H}_{2}$ then slowly falls over several hours.

The hydrogen breath test (HBT) has been described as the best indirect method for detecting hypolactasia in adults (Newcomer et al., 1975) and can be applied for other sugar intolerances (Metz et al., 
1976b). We recently adapted the HBT for use in infants and children (Maffei et al., 1976) and describe here the results obtained by this technique when investigating a group of infants and children for possible lactose malabsorption.

\section{Subjects and methods}

Twenty-three patients aged 2 months to 13 years with diarrhoea of more than 2 weeks' duration for which no cause had been found were studied (Table 1), and

Table 1 Age of patients being investigated for chronic diarrhoea and duration of diarrhoea.

\begin{tabular}{lllr}
\hline Age & No. of patients & Duration & No. of patients \\
\hline $2-12 \mathrm{~m}$ & 6 & $15-30 \mathrm{~d}$ & 5 \\
$1-2 \mathrm{yr}$ & 7 & $1-12 \mathrm{~m}$ & 12 \\
$2-6 \mathrm{yr}$ & 6 & $>1 \mathrm{yr}$ & 6 \\
$6-13 \mathrm{yr}$ & 4 & & \\
\hline
\end{tabular}

a further 8 children with suspected or proven coeliac disease were also investigated. 6 children aged 5 months to 5 years without diarrhoea or other gastrointestinal symptoms, 4 of whom were being investigated for failure to thrive, acted as controls.

The HBT was performed in children aged less than 6 years as previously described (Maffei et al., 1976): after an 8-hour fast a short catheter (FG 8-12) with a terminal opening was passed through a nostril to the oropharynx just above the site of the gag reflex and the free end taped to the cheek. Breath samples were collected before and every half hour for 2 to $4 \frac{1}{2}$ hours after an oral lactose load $(2 \mathrm{~g} / \mathrm{kg}$ body weight, maximum $50 \mathrm{~g}$, in a $10-20 \%$ solution); by carefully observing the respiratory movements, $2-5 \mathrm{ml}$ of air was aspirated into a polypropylene syringe towards the end of each expiration until a total of $30 \mathrm{ml}$ was collected. $\mathrm{H}_{2}$ concentration was measured by gas chromatography (Metz et al., 1976a) and expressed as parts per million (ppm). One child aged 5 and all those over 6 years were tested by the end-expiratory HBT technique as described for adults (Metz et al., 1976a). Symptoms were recorded during the test and for a least 24 hours after it, mainly by the mother at home.

In 10 patients and 2 controls blood glucose levels were measured after the oral lactose load concurrently with the HBT. Capillary blood was obtained at time zero and at half-hourly intervals for 2 hours; blood glucose concentration was estimated by the glucose oxidase method (Trinder, 1969). A rise of blood glucose concentration of greater than $20 \mathrm{mg} / 100 \mathrm{ml}(1 \cdot 1 \mathrm{mmol} / \mathrm{l})$ was considered normal.

Intestinal biopsy was performed at the duodeno- jejunal junction in 21 patients and 4 controls as part of their investigative procedure using the Watson modification of the paediatric Crosby capsule. Histological appearances were graded as normal (grade 1), increase in inflammatory cells accompanied by only slight villous broadening and shortening (grade 2), partial villous atrophy (grade 3), or subtotal villous atrophy (grade 4). Lactase activity was estimated in biopsy specimens from 11 patients and 3 controls. Specimens, deep frozen in liquid nitrogen and stored at $-80^{\circ} \mathrm{C}$, were assayed for lactase activity per $\mathrm{g}$ of mucosa by the method described by Plotkin and Isselbacher (1964) modified by Arthur (1966).

\section{Results}

Table 2 summarizes the results in individual cases. Of the 6 control patients, no $\mathrm{H}_{2}$ was detected in 4 and the fifth produced a very low level of doubtful significance. The last child had an early rise and fall of $\mathrm{H}_{2}$, suggestive of small bowel colonization (Metz et al., 1976c); this was subsequently proved by culture of jejunal juice (total aerobes $1.3 \times 10^{6} / \mathrm{ml}$, total anaerobes $3 \cdot 8 \times 10^{4} / \mathrm{ml}$ ).

Sixteen of the 23 patients with chronic diarrhoea produced $\mathrm{H}_{2}$ after lactose ingestion. 3 patients (Cases 7-9) had diarrhoea during or shortly after the test; these had the highest levels of breath $\mathrm{H}_{2} .3$ others (Cases 11-13) with a peak $\mathrm{H}_{2}$ higher than $40 \mathrm{ppm}$, and one (Case 17) with an $\mathrm{H}_{2}$ concentration of $25 \mathrm{ppm}$ had symptoms in the 24 hours after the test (diarrhoea, pain, excessive flatus, or borborygmi). 2 children (Cases 8 and 10) had the early rise and fall of $\mathrm{H}_{2}$ suggestive of colonization and a second peak suggestive of hypolactasia. Colonization of the jejunum was again confirmed by culture of jejunal fluid and hypolactasia was proved by low lactase levels in the jejunal mucosa. 3 further patients (Cases $22,24,25$ ) complained of symptoms, yet little or no $\mathrm{H}_{2}$ appeared in the breath. When considered with other parameters measured it is likely that these symptoms were coincidental.

There was no correlation between histopathological abnormalities of the jejunal mucosa and $\mathbf{H}_{2}$ production, nor between lactase levels and $\mathbf{H}_{2}$ production, though there was a good correlation between lactase levels and histological appearances (Table 2). Neither was there a correlation between the blood glucose rise and $\mathrm{H}_{2}$ production. However, the HBT result correlated strongly with the longterm follow-up on a lactose-free diet (LFD) (Table 2). All 12 patients with peak $\mathrm{H}_{2}>24$ ppm improved on LFD with complete resolution of symptoms. One patient (Case 19) with an $\mathrm{H}_{2}$ rise of $21 \mathrm{ppm}$ improved despite an unrestricted diet, as did 3 
Table 2 Comparison of hydrogen breath test (HBT) with symptoms during the test, small intestinal histology, intestinal lactase activity, lactose tolerance test (LTT), small intestinal bacteriology, and follow-up on a lactose-free diet (LFD)

\begin{tabular}{|c|c|c|c|c|c|c|c|c|c|}
\hline \multirow{2}{*}{$\begin{array}{l}\text { Case } \\
\text { no. }\end{array}$} & \multirow[b]{2}{*}{ Test symptoms } & \multicolumn{3}{|c|}{$\begin{array}{l}H B T, \\
H_{2} \text { concentration (ppm) }\end{array}$} & \multirow[b]{2}{*}{ Histology* } & \multirow[b]{2}{*}{ Lactase } & \multirow[b]{2}{*}{$\underset{(m g / 100 m l)}{L T T}$} & \multirow[b]{2}{*}{$\begin{array}{l}\text { Bacteriology } \\
\text { (organisms } / \text { ml) }\end{array}$} & \multirow[b]{2}{*}{ Follow-up } \\
\hline & & 0 & $30-60$ & $\underset{90 \rightarrow}{\text { Maximum }}$ & & & & & \\
\hline \multicolumn{10}{|c|}{ Controls } \\
\hline & None & 0 & $\mathbf{0}$ & $\mathbf{0}$ & - & - & Normal & 一 & \\
\hline $\begin{array}{l}\mathbf{2} \\
\mathbf{3}\end{array}$ & $"$ & $\begin{array}{l}0 \\
0\end{array}$ & $\begin{array}{l}\mathbf{0} \\
\mathbf{0}\end{array}$ & 0 & $1-2$ & Normal & Normal & $\overline{-}$ & \\
\hline 4 & ", & 0 & $\begin{array}{l}\mathbf{0} \\
\mathbf{0}\end{array}$ & $\begin{array}{l}0 \\
0\end{array}$ & $\overline{2-3}$ & $\overline{\text { Very low }}$ & Z & 二 & \\
\hline 5 & $\ddot{\prime \prime}$ & 0 & $\mathbf{0}$ & 4 & $1-2$ & Normal & - & - & \\
\hline 6 & $"$, & 0 & 6 & $\mathbf{0}$ & $1-2$ & - & - & $>10^{6}$ & \\
\hline \multicolumn{10}{|c|}{ Chronic diarrhoea } \\
\hline 7 & D during test & $\mathbf{0}$ & 2 & 161 & $1-2$ & - & $<20$ & - & Symptoms resolved on LFD \\
\hline 8 & D after test & 14 & 93 & 103 & 2 & Low & - & $2.9 \times 10^{s}$ & ", $\quad$ " $\quad$ " \\
\hline $\begin{array}{r}9 \\
10\end{array}$ & D during test & $\begin{array}{r}4 \\
12\end{array}$ & $\begin{array}{r}5 \\
54\end{array}$ & $\begin{array}{l}78 \\
70\end{array}$ & $\overline{2}$ & $\bar{L}$ & $\overline{-}$ & $\bar{x}_{10^{6}}$ & Well on LFD " "'w, then füll diet \\
\hline 11 & Colicky pain & 0 & $\begin{array}{r}34 \\
9\end{array}$ & 52 & 2 & Low & - & - & Symptoms resolved on LFD \\
\hline 12 & $\begin{array}{l}\text { Flatus; } \\
\text { D later }\end{array}$ & 0 & 0 & 50 & 1 & - & $<20$ & - & $\begin{array}{l}\text { Symptoms resolved on sucrose-free } \\
\text { + LFD }\end{array}$ \\
\hline 13 & Flatus; pain & 0 & 0 & 41 & 1 & Normal & Normal & - & Symptoms resolved on LFD \\
\hline 14 & None & $\mathbf{0}$ & $\mathbf{0}$ & 34 & 1 & Normal & - & Normal & $\begin{array}{l}\text { Symptoms resolved on LFD } 8 \mathrm{w} \text {, } \\
\text { then full diet }\end{array}$ \\
\hline 15 & None & 11 & 22 & 43 & 1 & - & - & Normal & Symptoms resolved on LFD \\
\hline 16 & None & 6 & 6 & 38 & - & - & Normal & $\begin{array}{l}\text { Pathogenic } \\
\text { E. coli in } \\
\text { stool }\end{array}$ & " $\quad$ " $\quad, \quad$, \\
\hline 17 & $\begin{array}{l}\text { Flatus; } \\
\text { D later }\end{array}$ & 0 & $\mathbf{0}$ & 25 & - & - & Normal & - & " $\quad, \quad, \quad$, \\
\hline 18 & None & $\mathbf{0}$ & $\mathbf{0}$ & 25 & - & - & - & Normal & $\begin{array}{llll}\| & \| & ,\end{array}$ \\
\hline 19 & None & 0 & $\mathbf{0}$ & 21 & $1-2$ & Normal & - & & Improved on no specific treatment \\
\hline 20 & None & $\mathbf{0}$ & $\mathbf{0}$ & 9 & $1-2$ & - & - & - & Improved on no specific treatment \\
\hline 21 & None & 3 & 3 & 10 & - & - & $<20$ & - & Lost to follow-up; ? diagnosis \\
\hline 22 & $\begin{array}{l}\text { Excessive } \\
\text { flatus }\end{array}$ & 0 & $\mathbf{0}$ & 4 & 1 & - & - & Normal & - \\
\hline 23 & None & $\mathbf{0}$ & $\mathbf{0}$ & $\mathbf{0}$ & - & - & $<20$ & - & Improved on full diet \\
\hline 24 & D at $24 \mathrm{~h}$ & 8 & 8 & 8 & 1 & Normal & - & - & $\begin{array}{l}\text { No better on LFD } \\
\text { Hyposucrasia later diagnosed }\end{array}$ \\
\hline 25 & D at $24 \mathrm{~h}$ & 0 & 0 & $\mathbf{0}$ & 1 & - & - & - & $\begin{array}{l}\text { No better on LFD nor sucrose-free } \\
\text { diet } \\
\text { Improved on GFD }\end{array}$ \\
\hline 26 & None & $\mathbf{0}$ & 0 & 0 & $1-2$ & Normal & - & - & Lost to follow-up \\
\hline 27 &, & $\mathbf{0}$ & 0 & 0 & 1 & - & - & - & Improved on full diet \\
\hline 28 & ", & $\mathbf{0}$ & $\mathbf{0}$ & 0 & - & - & - & - & Lost to follow-up \\
\hline & ", & 0 & 0 & 0 & - & - & - & - & No better on LFD \\
\hline \multicolumn{10}{|c|}{$\begin{array}{l}\text { Coeliac disease } \\
\text { Untreated }\end{array}$} \\
\hline 30 & None & 0 & 0 & 16 & 3 & Very low & $<20$ & - & Resolved on GFD without LFD \\
\hline 31 & , & 0 & $\mathbf{0}$ & 16 & 2-3 & & - & - & Resolved on GFD without LFD \\
\hline 32 & ," & 0 & $\mathbf{0}$ & 9 & 3 & Very low & - & - & Defaulted from follow-up \\
\hline \multirow{2}{*}{$\begin{array}{l}\text { Treated } \\
\mathbf{3 4}\end{array}$} & $"$ & 13 & 20 & 13 & 4 & Very low & - & - & Resolved on GFD without LFD \\
\hline & None & $\mathbf{0}$ & 4 & 68 & 2-3 & - & - & - & $\begin{array}{l}\text { Treated } 8 \mathrm{yr} \text {; inadequate gluten } \\
\text { exclusion }\end{array}$ \\
\hline 35 & ," & $\mathbf{0}$ & 0 & 19 & $1-2$ & - & Normal & - & Well on GFD only; no LFD \\
\hline 36 & $"$ & $\mathbf{0}$ & $\mathbf{0}$ & 0 & - & - & Normal & - & " , , " $, ", \quad$, \\
\hline 37 & 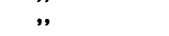 & $\mathbf{0}$ & $\mathbf{0}$ & 9 & 1 & Normal & - & - & " , " \\
\hline
\end{tabular}

$* 1=$ normal; $2=$ increase in inflammatory cells with slight villous broadening and shortening; $3=$ partial villous atrophy; $4=$ subtotal villous atrophy.

D = diarrhoea $\left(1 \mu \mathrm{mol} / 1 \mathrm{H}_{2}=22 \mathrm{ppm} \mathrm{H}_{2}\right)$. GFD := gluten-free diet.

(Cases 20, 23, 27) with either no $\mathrm{H}_{2}$ rise or a rise of $<10 \mathrm{ppm} .3$ others with no rise in $\mathrm{H}_{2}$ concentration (Cases 24, 25, 29) were put on to LFD, but showed no improvement.

Four patients known to have coeliac disease were tested. All had been free of gastrointestinal symptoms after 6 months or more on a gluten-free diet and 3 of them had an $\mathrm{H}_{2}$ rise $<20 \mathrm{ppm}$, indicating only mild lactose intolerance. The fourth had an abnormal HBT and at biopsy was found to have partial villous atrophy despite 8 years on apparent gluten exclusion. Of 4 suspected coeliacs, all had partial or subtotal villous atrophy at biopsy. However, none had an HBT rise of more than 16 ppm nor symptoms during the test, suggesting reasonably good lactose absorption. 


\section{Discussion}

Diagnosis of lactose intolerance in children is not easy. Most centres make it by the lactose tolerance test (LTT), by estimation of stool-reducing substances after a lactose load, or in many cases by a trial of LFD alone. None of these methods is satisfactory. Intermittent breath sampling for analysis of breath $\mathrm{H}_{2}$ is now established as the most accurate indirect test of disaccharide intolerance in adults and we have now adapted this technique for children.

In children the first problem is which test to use as a criterion with which to compare the breath $\mathrm{H}_{2}$ result. The most logical criterion seems to be a comparison with jejunal lactase activity. This was estimated in 14 biopsy samples in this series and the correlation between low lactase and increased $\mathrm{H}_{2}$ production was poor (Table 2). Lactase levels are highest in the mid-ileum (Asp et al., 1975), while our biopsies were taken at the duodenojejunal flexure, and the HBT analyses the end effect of the overall absorptive function. Thus in patients with subtotal villous atrophy and low jejunal lactase but normal mucosa lower in the small bowel (e.g. untreated coeliac disease) a negative HBT result would be expected. This has been previously reported in adults with coeliac disease (Metz et al., 1976d) and seems to be a more valuable index of lactose 'tolerance' than lactase activity at one point in the small intestine. Similar reasoning could apply to the lack of correlation between the histology of the small bowel and breath $\mathrm{H}_{2}$ production in our patients.

As for the relationship between HBT and the rise in glucose after lactose (LTT), it is already known that false-positive results occur in $23-30 \%$ of oral LTTs in children (Krasilnikoff et al., 1975) and occasionally patients with sugar intolerance show a normal rise in blood glucose. A further study (Harrison and Walker-Smith, 1977) has confirmed the lack of correlation between clinical lactose intolerance and disaccharidase activity, small intestinal morphology, and LTTs. Thus the only criteria against which to judge the accuracy of the HBT in children are the occurrence of symptoms during an LTT and the long-term follow-up on an LFD. The 3 patients with diarrhoea during the test also had the highest concentration of $\mathbf{H}_{2}$ in the breath. Several others with $\mathrm{H}_{2}$ rise of $>25 \mathrm{ppm}$ had symptoms during the test or during the 24 hours after the completion of the test. Careful follow-up for up to 16 months was possible in all cases with an HBT result of $>9 \mathrm{ppm}$ and in most other cases as well. A very good correlation was shown between an HBT result $>25 \mathrm{ppm}$ and response to LFD.
Those cases with between 9 and 25 ppm appear to be a 'grey zone', i.e. some were better despite milk in the diet whereas others were later shown to have coeliac disease and responded symptomatically to a gluten-free diet-the grey-zone positivity in these cases does indeed reflect some degree of lactose malabsorption. Of those with an HBT of $<10 \mathrm{ppm}$, none responded to an LFD, confirming that lactose intolerance was not in fact their problem.

False-positive HBT results can occur in two situations. If the child has not been adequately fasted and $\mathrm{H}_{2}$ is found in high concentration in the basal sample, then fluctuations above the basal level over the next 3 hours could reflect a variation in colonic $\mathrm{H}_{2}$ production from the substrate ingested at the previous meal. Secondly, the $\mathrm{H}_{2}$ concentration rises when children sleep, so that a low or moderate basal reading (e.g. $10 \mathrm{ppm}$ ) with the child awake may rise to $>20 \mathrm{ppm}$ if the child is asleep. This is probably an effect of hypoventilation during sleep with a consequent rise in concentration of expired $\mathrm{H}_{2}$ (Solomons and Viteri, 1976). Both these situations can be avoided by adequate fasting and by taking into account any rise observed in samples taken with the child asleep.

False-negatives could be due to inability of the colonic bacteria to produce $\mathrm{H}_{2}$ from nonabsorbed lactose; this has been found in about $2 \%$ of adults (Metz et al., 1976d). Bad breath sampling technique or marked hyperventilation, such as during crying, may reduce the concentration of $\mathbf{H}_{2}$ to below that found at rest. A 'false-negative' HBT in association with a flat jejunal biopsy or low jejunal lactase activity probably reflects good absorption lower in the small intestine. In our experience a history of 'malabsorption-like' stools associated with low $\mathbf{H}_{2}$ production, $\epsilon$ specially if the onset of $\mathrm{H}_{\varepsilon}$ production is late (e.g. $180-240 \mathrm{~min}$ after ingestion of lactose), is very suggestive of coeliac disease.

The pattern of $\mathrm{H}_{2}$ production is worthy of comment. Although there is not a direct relationship between the amount of lactose malabsorbed and the volume of $\mathrm{H}_{2}$ produced when comparing different individuals, we noted that a sharp rise in $\mathrm{H}_{2}$ concentration at 60 or 90 minutes was associated with more prominent symptoms during the test and the highest $\mathrm{H}_{2}$ concentrations during the following hours, indicating that severe lactose malabsorption tends to accelerate the small intestinal transit more than mild malabsorption, producing early arrival of the lactose in the caecum and early evolution of $\mathrm{H}_{2}$.

A very early rise and fall in $\mathrm{H}_{2}$ has been observed after glucose ingestion in two-thirds of patients with small intestinal colonization (Metz et al., 1976c). Only 2 children with chronic diarrhoea had an HBT 
suggestive of colonization and this was confirmed on culture of the jejunal juice. However, we cannot be sure that other children were not colonized since culture was not done routinely in all cases (Table 2). These data suggest that colonization is an uncommon cause for the diarrhoea in our group of children, though in developing countries where secondary disaccharidase deficiency associated with gastrointestinal infection is far more common, the HBT may be useful in suggesting a diagnosis of upper gastrointestinal bacterial colonization in addition to lactose intolerance.

None of our controls produced $\mathrm{H}_{2}$ in a manner suggestive of hypolactasia, though the test suggested bacterial colonization in one child who presented with failure to thrive; this was subsequently confirmed by culturing the jejunal juice. Theoretically mild hypolactasia could be induced in a symptomfree child by overload but this is very unlikely in children under 5 years of age (Cook, 1967).

Only 2 of our children, those with the highest $\mathrm{H}_{2}$, would have been detected by testing stools for reducing substances at the time of the test, and measurement of reducing substances would have missed the diagnosis in the other 10 patients with an $\mathrm{H}_{2}$ concentration above $24 \mathrm{ppm}$ whose follow-up showed that exclusion of lactose or milk from their diet was needed for the resolution of the diarrhoea: The opposite was true for those with a $\mathrm{H}_{2}$ below $25 \mathrm{ppm}$, their diarrhoea having improved without milk withdrawal. Based on these results we suggest that $\mathrm{H}_{2}$ peaks above $60 \mathrm{ppm}$ are indicative of severe lactose intolerance; peaks between 25 and $60 \mathrm{ppm}$ would usually suggest moderate to severe lactose intolerance and those below $25 \mathrm{ppm}$, though not normal, reflect only minimal lactose malabsorption.

We conclude, therefore, that the HBT gives a useful prognostic guide to the efficacy of an LFD in the treatment of chronic diarrhoea in children. It is much more acceptable to children than intestinal biopsy (Maffei et al., 1976) and eliminates the necessity of the time consuming careful biochemical analyses required for enzyme determination. The good correlation between HBT and response to lactose withdrawal suggests that the HBT is a better indicator of clinical lactose 'tolerance' than either estimation of jejunal lactase activity or an LTT. In contrast to the stool/sugar test the HBT does not depend on the patients having diarrhoea during an LTT to establish the diagnosis, and it is therefore an appropriate outpatient procedure. The HBT can easily be repeated as required to test for recovery, and in addition, unsuspected cases of upper gastrointestinal bacterial colonization may be detected during the test.
We are grateful to Drs. T. D. Kellock, D. J. A. Jenkins, and E. N. Rowlands for advice and criticism; to Mrs. J. Sacks and Mr. V. Oberholzer, Queen Elizabeth Hospital for Children, London, for lactase estimations; and to Drs. J. B. Burke, I. Kessel, and L. Sinclair for allowing us to study their patients; to Staff Nurse Sue Waterman for skilful assistance; and to Mrs. Pat Evans for preparing the manuscript.

H.V.L.M. is in receipt of a grant from the Fundacao de Amparo a Pesquisa do Estado de São Paulo, Brasil. G.M. is in recept of the T. K. Stubbins Fellowship of the Royal College of Physicians, London.

\section{References}

Arthur, A. B. (1966). Intestinal disaccharidase deficiency in children with coeliac disease. Archives of Disease in Childhood, 41, 519-524.

Asp, N. G., Gudmand-Høyer, E., Andersen, B., Berg, N-O., and Dahlqvist, A. (1975). Distribution of disaccharidases, alkaline phosphatase and some intracellular enzymes along the human small intestine. Scandinavian Journal of Gastroenterology, 10, 647-651.

Bond, J. H., and Levitt, M. D. (1972). Use of pulmonary hydrogen measurements to quantitate carbohydrate absorption. Journal of Clinical Investigation, 51, 1219-1225.

Calloway, D. H., Colasito, D. J., and Mathews, R. D. (1966). Gases produced by human intestinal microflora. Nature, 212, $1238-1239$.

Cook, G. C. (1967). Lactase activity in newborn and infant Baganda. British Medical Journal, 1, 527-530.

Harrison, M., and Walker-Smith, J. A. (1977). Reinvestigation of lactose intolerant children: lack of correlation between continuing lactose intolerance and small intestinal morphology, disaccharidase activity, and lactose tolerance tests. Gut, 18, 48-52.

Kerry, K. R., and Anderson, C. M. (1964). A ward test for sugar in faeces. Lancet, 1, 981-982.

Krasilnikoff, P. A., Gudmand-Høyer, E., and Moltke, H. H. (1975). Diagnostic value of disaccharide tolerance tests in children. Acta Paediatrica Scandinavica, 64, 693-698.

Levin, B., Abraham, J. M., Burgess, E. A., and Wallis, P. G. (1970). Congenital lactose malabsorption. Archives of Disease in Childhood, 45, 173-177.

Levitt, M. D. (1969). Production and excretion of hydrogen gas in man. New England Journal of Medicine, 281, 122-127.

Levitt, M. D., and Ingelfinger, F. J. (1968). Hydrogen and methane production in man. Annals of the New York Academy of Sciences, 150, 75-81.

Maffei, H. V. L., Metz, G. L., and Jenkins, D. J. A. (1976). Hydrogen breath test: adaptation of a simple technique to infants and children. Lancet, 1, 1110-1111.

Metz, G., Gassull, M. A., Leeds, A. R., Blendis, L. M., and Jenkins, D. J. A. (1976a). A simple method of measuring breath hydrogen in carbohydrate malabsorption by endexpiratory sampling. Clinical Science and Molecular Medicine, 50, 237-240.

Metz, G., Jenkins, D. J. A., Newman, A., and Blendis, L. M. (1976b). Breath hydrogen in hyposucrasia. Lancet, 1 , 119-120.

Metz, G., Drasar, B. S., Gassull, M. A., Jenkins, D. J. A., and Blendis, L. M. (1976c). Breath-hydrogen test for small-intestinal bacterial colonisation. Lancet, 1, 668-669. 
Metz, G., Blendis, L. M., and Jenkins, D. J. A. (1976d). Hydrogen breath test for lactase deficiency. New England Journal of Medicine, 294, 730.

Newcomer, A. D., and McGill, D. B. (1966). Lactose tolerance tests in adults with normal lactase activity. Gastroenterology, 50, 340-346.

Newcomer, A. D., McGill, D. B., Thomas, P. J., and Hofmann, A. F. (1975). Prospective comparison of indirect methods for detecting lactase deficiency. New England Journal of Medicine. 293, 1232-1235.

Plotkin, G. R., and Isselbacher, K. J. (1964). Secondary disaccharidase deficiency in adult celiac disease (nontropical sprue) and other malabsorption states. New England Journal of Medicine, 271, 1033-1037.
Solomons, N. W., and Viteri, F. (1976). Breath hydrogen during sleep. Lancet, 2, 636.

Sunshine, P., and Kretchmer, N. (1964). Studies of small intestine during development. III. Infantile diarrhea associated with intolerance to disaccharides. Pediatrics, 34, 38-40.

Trinder, P. (1969). A method for determination of blood glucose. Annals of Clinical Biochemistry, 6, 24-26.

Correspondence to Dr. H. L. V. Maffei, Faculdade de Ciencias Medicas e Biologicas, 18600 Botucatu, São Paulo, Brasil. 